\title{
Daily Profile of glut1 and glut4 Expression in Tissues Inside and Outside the Blood-Brain Barrier in Control and Streptozotocin- Treated Rats
}

\author{
D. ŠOLTÉSOVÁ ${ }^{1}$, A. VESELÁ ${ }^{1}$, B. MRAVEC ${ }^{2,3}$, I. HERICHOVÁ ${ }^{1}$
}

${ }^{1}$ Department of Animal Physiology and Ethology, Comenius University in Bratislava, Bratislava, Slovak Republic, ${ }^{2}$ Institute of Pathophysiology, Faculty of Medicine, Comenius University in Bratislava, Bratislava, Slovak Republic, ${ }^{3}$ Institute of Experimental Endocrinology, Slovak Academy of Sciences, Bratislava, Slovak Republic

Received March 15, 2013

Accepted June 24, 2013

\section{Summary}

Glucose is molecule usually studied in relation to metabolism. Except for this traditional view, it is known that under certain conditions glucose can serve as a signal molecule for the circadian system. The circadian system is entrained by relevant synchronizing cues that can be tissue-dependent. Central oscillator is synchronized mainly by light-dark cycle, while peripheral oscillators can be entrained by food intake. Glucose transport in the organism is controlled by insulin dependent and independent mechanism. Therefore, we employed streptozotocininduced diabetes to elucidate the influence of metabolic changes on glucose transporter (glut1, glut4) 24-h expression profile in peripheral oscillators in tissues, inside (frontal cortex, cerebellum) and outside (heart) the blood-brain barrier. Diabetes was induced by streptozotocin injection. Seventeen days later, sampling was performed during a 24-h cycle. Gene expression was measured using real-time PCR. We observed downregulation of glut1 and glut4 expression in the heart of diabetic rats. The expression of glut1 and glut4 in brain areas was not down-regulated, however, we observed trend to phase advance in glut1 expression in the cerebellum. These results may indicate higher glucose levels in diabetic brain, which might influence regulation of clock gene expression in different manner in brain compared to periphery.

\section{Key words}

Frontal cortex - Heart - Cerebellum • Glucose transporter • Circadian

\section{Corresponding author}

Dorota Šoltésová, Department of Animal Physiology and Ethology, Faculty of Natural Sciences, Comenius University in Bratislava, Mlynska dolina B-2, 84215 Bratislava, Slovak Republic. E-mail: soltesova@fns.uniba.sk

\section{Introduction}

Circadian system is entrained by relevant environmental cues, such as light-dark cycle, to synchronize internal biological oscillations with external daily changes. Proper synchronization allows organisms to adapt to upcoming changes in advance and achieve the appropriate physiological response according to the current daytime (Aschoff 1981).

Central circadian oscillator of hierarchically organized mammalian circadian system resides in the suprachiasmatic nuclei (SCN) of the hypothalamus. Central oscillator synchronizes peripheral oscillators located in other tissues and organs. Beside the light-dark cycle, the circadian system can be synchronized by additional relevant cues, including humoral signals and metabolites (Challet 2010).

Circadian oscillators generate circadian rhythms via tightly regulated changes in clock gene expression with subsequent posttranscriptional and posttranslational modifications. Clock gene expression is regulated by mechanism of feedback loop, where protein products of some genes (per, cry) inhibit their own transcription. The transcriptional factors BMAL1 and CLOCK play a key 
role in this loop. Protein heterodimer CLOCK/BMAL1 initiates expression of target genes, including the clock genes period (per1, per2, per3) and cryptochrome (cryl, cry2), by binding to their E-box regulatory enhancer sequence. Negative feedback is achieved by PER/CRY heterodimer interaction with the CLOCK/BMAL1 complex, which results in inhibition of per and cry transcription. As a result, the formation speed of PER and CRY proteins cannot prevail over PER phosphorylation by casein-kinase 1 delta and casein-kinase 1 epsilon. Proteins PER and CRY are subsequently swiftly degraded by $\beta$-TrCP1 and FbXL3e3 ubiquitin ligase complexes. Lack of presence of PER/CRY repressor complex leads to the activation of a new transcriptional cycle by the CLOCK/BMAL1 heterodimer (Shearman et al. 2000, Albrecht 2006, Takahashi et al. 2008).

It is well known that under certain pathophysiological conditions, including metabolic disorders, disturbances in function of the circadian system occur (Barnard et al. 2008, Laposky et al. 2008). Diabetes is characteristic with massive changes in plasma glucose, ketones and fatty acid levels, which can affect functioning of peripheral oscillators (Kohsaka et al. 2007, Oishi et al. 2009). During experimental streptozotocininduced diabetes, plasma glucose levels are markedly elevated (Young et al. 2002, Oishi et al. 2004). Streptozotocin-induced diabetes is commonly used model of diabetes, where streptozotocin specifically damages pancreatic $\beta$-cells, leading to permanent inhibition of insulin secretion (Šoltésová and Herichová 2011). Diurnal rhythm of energy metabolism in diabetic animals differs from control animals. The highest level of carbohydrate utilization occur at the middle of the light phase in diabetic rats compared to maximal levels achieved at the end of the dark phase in the control group (Ichikawa et al. 2000). It was observed, that daytime feeding schedule caused more efficient phase shifts of circadian clock genes expression in diabetic rats than in control animals. Entrainment of the activity rhythm of diabetic rats was accomplished after 5 days of daytime feeding regimen, while the complete reversion of the activity pattern in the control group was still not observed (Wu et al. 2012). Daytime restricted feeding shifted the acrophase of rhythmic profile of plasma glucose levels in diabetic rats to antiphase compared to control animals. This could possibly indicate smaller stability of circadian system during diabetes and its higher sensitivity to feeding regime (Wu et al. 2012).

Glucose alone can influence the responsiveness of the circadian system to photic signals. It was reported that a reduced glucose availability inflicted by intraperitoneal injection of 2-deoxy-D-glucose is associated with attenuation of the light-induced phase resetting of the mouse circadian clock (Challet et al. 1999).

Addition of glucose solution to the culture medium can induce circadian rhythm in rat-1 fibroblast cell culture, followed by transient down-regulation of perl and per2 expression (Hirota et al. 2002). Furthermore, continuous glucose infusion is able to affect the expression of per 2 in the SCN and to shift phase of per 2 expression in the rat liver (Iwanaga et al. 2005). It was previously observed, that diabetic animals exhibit altered daily profile of clock gene expression in the heart, liver and kidney (Young et al. 2002, Oishi et al. 2004, Herichová et al. 2005).

Glucose plasma levels in healthy individuals exhibit a clear-cut circadian rhythm with peak values occurring immediately before the onset of the active phase (La Fleur et al. 1999). Daily changes in glucose tolerance were also observed. The percentage of glucose removed from plasma per minute is higher at the beginning of the active phase of the 24-hour cycle compared to the values of glucose uptake achieved at the end of the active period. During the active period, glucose tolerance is gradually declining (Lee et al. 1992, La Fleur et al. 2001). These endogenous daily rhythms are driven and maintained by the SCN that control glucose plasma levels via innervations of the paraventricular nucleus, arcuate nucleus and the autonomic nervous system (La Fleur 2003, Kalsbeek et al. 2004, Cailotto et al. 2008, Froy 2010).

Glucose uptake by tissues differs between peripheral oscillators. Glucose transport in neural tissues is mediated by GLUT1 and GLUT3 glucose transporters independently of insulin levels. This implies unaffected glucose accessibility in the brain in insulin-dependent diabetes, characterized with insulin deficiency. Other tissues e.g. muscle and liver, are dependent on insulinmediated glucose transport, mainly provided by insulinregulated GLUT4 glucose transporter (Ebeling et al. 1998, Duelli and Kuschinsky 2001, Arble and Sandoval 2013).

Because of these substantial changes in glucose plasma levels and metabolism during diabetes, we focused on the expression of glucose transporters. The aim of present study was to ascertain daily profile of glut 1 and glut4 expression in peripheral oscillators inside 
(cerebellum, frontal cortex) and outside (heart) of the blood-brain barrier in control rats and rats with streptozotocin-induced diabetes and to consider involvement of glut1 and glut4 in diabetes-dependent changes in circadian system.

\section{Methods}

Male Wistar rats $(n=52)$ were at the age of 16-weeks obtained from the Dobra Voda breeding facility (Slovak Republic). Animals (275-300 g body weight) were housed under controlled conditions $\left(22 \pm 2{ }^{\circ} \mathrm{C}\right)$ and for two weeks synchronized to a 12:12 light:dark (LD) cycle, with lights on from 23:00 h (Zeitgeber time (ZT) 0) to $11: 00 \mathrm{~h}(\mathrm{ZT} 12)$. The Zeitgeber time is a relative measure of time reflecting the LD regimen in the animal facility, where ZT 0 is defined as the beginning of the light phase of the 24-h cycle and the dark phase starts at ZT 12. Food and water were provided ad libitum. After the acclimatization period, control and experimental groups of animals were established.

The experimental group received a single intraperitoneal injection of streptozotocin (STZ) (65 mg/kg body weight, Sigma, USA) dissolved in $0.1 \mathrm{M}$ citrate buffer ( $\mathrm{pH} 4.5$ ) injected in a volume of less than $1 \mathrm{ml}$ per rat (Rerup 1970). Animals in control group were injected with a vehicle (0.1 M citrate buffer with $\mathrm{pH} 4.5)$. Development of diabetes was monitored using PHAN $^{\circledR}$ diagnostic test strips for urine analysis (Pliva Lachema, Czech Republic).

Samples were taken on day 17-18 after STZ injection throughout the 24-h cycle (3 to 6 animals per group and time point) at ZT 14, ZT 17, ZT 20, ZT 23, ZT 4 and ZT 8 . Rats were anaesthetized by carbon dioxide and subsequently decapitated (3-6 animals per group and time point). Blood was collected into heparinized tubes, and plasma was stored at $-20{ }^{\circ} \mathrm{C}$ until analysis. Red light with low intensity was used when collecting blood samples during the dark period. Samples of the heart were immediately frozen in liquid nitrogen and stored at $-80^{\circ} \mathrm{C}$ until RNA extraction. The frontal cortex and cerebellum were dissected and frozen on dry ice and subsequently stored at $-80^{\circ} \mathrm{C}$ until RNA extraction.

The experimental protocol was approved by the Ethics Committee for the Care and Use of Laboratory Animals at Comenius University Bratislava. All experiments were performed in accordance with the European Directive 2010/63/EU on the protection of animals used for scientific purposes.
Plasma glucose levels were measured using a commercial kit (Glucosa Liquid 1000, Lachema, Czech Republic). Total RNA was isolated from tissue samples using the single-step method by acid guanidinium thiocyanate-phenolchloroform extraction (Chomczynski and Sacchi 1987) with the use of Tri reagent ${ }^{\circledR}$ (MRC, USA). First-strand cDNA synthesis was performed in RNA samples isolated from the heart and cerebellum using the ImProm-II ${ }^{\mathrm{TM}}$ Reverse Transcription System (Promega, USA) according to the manufacturer's instructions. First-strand cDNA synthesis in RNA samples isolated from the frontal cortex was carried out using a High Capacity RNA-to-cDNA Kit (Applied Biosystems, USA).

Aliquots of the cDNA (0.75-1 $\mu$ l of RT product) were analyzed for gene expression with the appropriate primers in $20-\mu \mathrm{l}$ real-time PCR reactions. The quantification of cDNA was performed by real-time PCR using a Step-One System (Applied Biosystems, USA).

Real-time PCR quantification of glut1 and glut4 expression was evaluated using a TaqMan ${ }^{\circledR}$ Fast Advanced Master Mix and TaqMan $\AA$ Gene Expression Assays Rn01417099_m1 (glut4), 4331182 TaqMan® Gene Expression Assays Rn01752377_m1 (glut1) according to the manufacturer's instructions (Applied Biosystems, USA). Real-time PCR conditions were: activation of AmpliTaq ${ }^{\circledR}$ Fast DNA Polymerase $\left(95^{\circ} \mathrm{C}\right.$, $20 \mathrm{~s})$, followed by 50 cycles of denaturation $\left(95^{\circ} \mathrm{C}, 1 \mathrm{~s}\right)$ and annealing $\left(60^{\circ} \mathrm{C}, 20 \mathrm{~s}\right)$. The fluorescent dye ROX served as an internal reference for normalization of the FAM fluorescent signal. Gene expression was normalized to the expression of rplp1 (ribosomal protein, large, P1).

Daily profiles of gene expression in relative values were fitted to a cosinor curve with a 24 -h period and when experimental data significantly matched the cosinor curve, its acrophases (peak time referenced to the time of lights on in the animal facility) were calculated with $95 \%$ confidence limits. Goodness of fit ( $\mathrm{R}$ value correlation coefficient) of the approximated curve was calculated by ANOVA (Nelson 1979, Klemfuss and Clopton 1993). An unpaired Student t-test was used to compare variables between groups. The data on the graphs are presented as arithmetic mean and standard error of the mean (SEM).

\section{Results}

The plasma glucose levels in diabetic rats $(32.50 \pm 2.03 \mathrm{mmol} / \mathrm{l})$ were significantly higher than in 

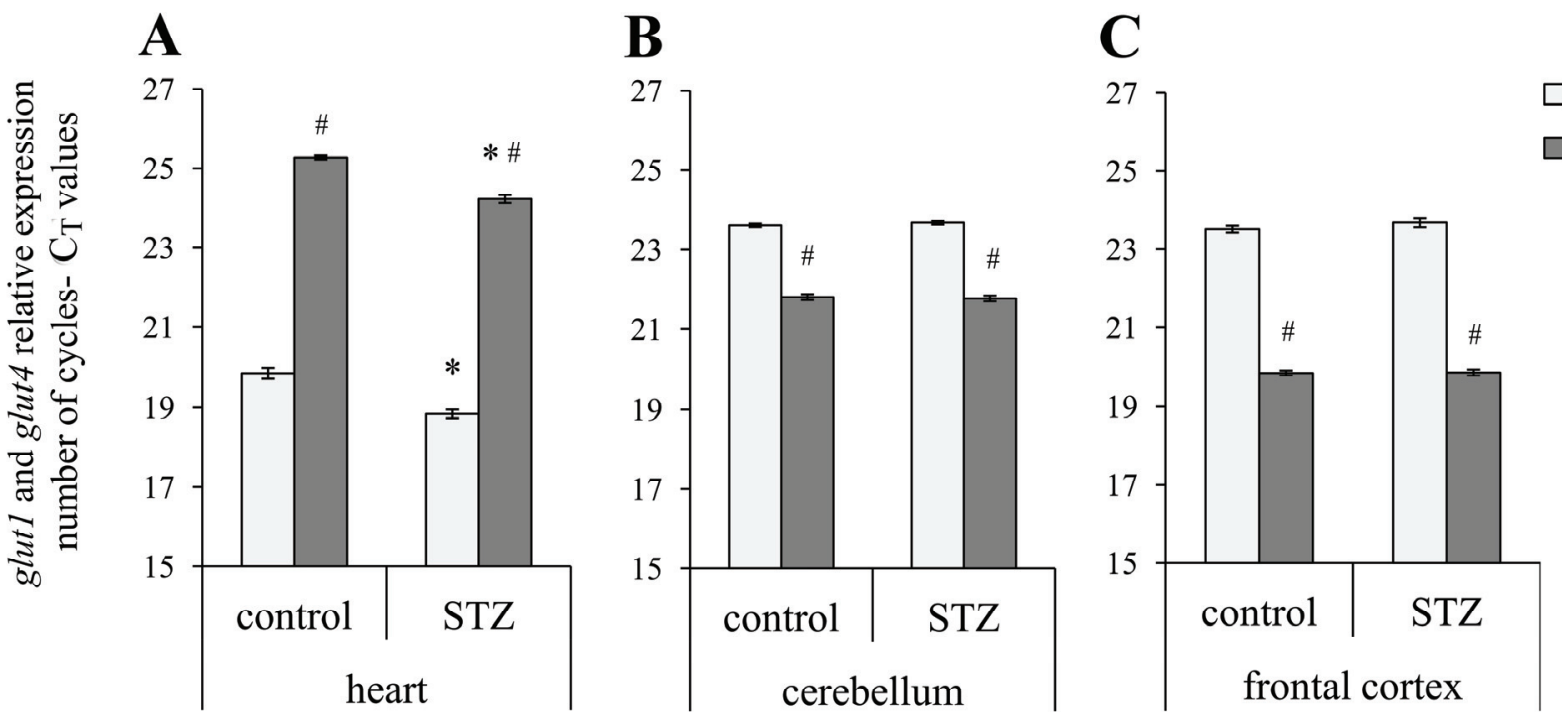

Fig. 1. Relative expression of g/ut1 (light columns) and glut4 (dark columns) in the heart (A), cerebellum (B) and frontal cortex (C) of control and diabetic rats (STZ). Relative expression is presented as threshold cycle values deducted from the total number of PCR cycles. $C_{T}$ represents the threshold cycle: the cycle number of PCR at which the fluorescence reaches the threshold in the amplification plot. Number of PCR cycles was 50 . Values are presented as mean \pm SEM $(n=19-25)$. Unpaired t-test: * significant difference between control and diabetic group $(\mathrm{P}<0.05)$, \# significant difference between g/ut1 and g/ut4 expression $(\mathrm{P}<0.001)$

Table 1. Cosinor analysis of gene expression in the heart, frontal cortex and cerebellum of control and diabetic rats.

\begin{tabular}{|c|c|c|c|c|c|c|c|c|}
\hline \multirow[b]{2}{*}{ Tissue } & \multirow[b]{2}{*}{ Gene } & \multicolumn{3}{|c|}{ Control } & \multicolumn{3}{|c|}{ STZ } & \multirow[b]{2}{*}{$\begin{array}{c}\text { Significant difference } \\
\text { in rhythm between } \\
\text { groups }\end{array}$} \\
\hline & & $\begin{array}{c}\text { Acrophase } \pm \\
\text { SEM } \\
{[\text { hh:mm] }}\end{array}$ & $\mathbf{R}$ & $\mathbf{P}<$ & $\begin{array}{c}\text { Acrophase } \pm \\
\text { SEM } \\
{[\text { hh:mm] }}\end{array}$ & $\mathbf{R}$ & $\mathbf{P}<$ & \\
\hline \multirow[t]{2}{*}{ Heart } & glut1 & & 0.19 & ns & & 0.17 & $\mathrm{~ns}$ & $\begin{array}{l}\text { down-regulation (t-test, } \\
\mathrm{P}<0.0001 \text { ) }\end{array}$ \\
\hline & glut4 & & 0.43 & ns & & 0.22 & ns & $\begin{array}{l}\text { down-regulation (t-test, } \\
\mathrm{P}<0.0001 \text { ) }\end{array}$ \\
\hline \multirow{2}{*}{$\begin{array}{l}\text { Frontal } \\
\text { cortex }\end{array}$} & glut1 & & 0.25 & ns & & 0.24 & ns & \\
\hline & glut4 & & 0.09 & ns & & 0.07 & ns & \\
\hline \multirow[t]{2}{*}{ Cerebellum } & glut1 & $14: 43 \pm 0: 57$ & 0.65 & 0.01 & $11: 17 \pm 1: 07$ & 0.56 & 0.05 & \\
\hline & glut4 & $13: 52 \pm 1: 03$ & 0.60 & 0.01 & $12: 49 \pm 0: 53$ & 0.68 & 0.001 & \\
\hline
\end{tabular}

Results of cosinor analysis describe the best-fitting cosinor curve significantly reflecting experimental data $(P<0.05, A N O V A)$. Acrophase represents time at which the fitted cosinor curve reached its maximum value in relation to the beginning of the light phase. Time is given as a Zeitgeber time (ZT, ZT 0 is related to beginning of the light phase). control - control rats, STZ - streptozotocin-treated rats, SEM - standard error expressed in hours and minutes, P - level of significance, ns - not significant, R - goodness of fit, downregulation - down-regulated expression (t-test)

control animals $(10.35 \pm 0.34 \mathrm{mmol} / \mathrm{l})$ on day 17 after STZ administration. The body weight of control animals (341.49 $\pm 4.04 \mathrm{~g})$ was significantly higher compared to that in diabetic animals $(282.41 \pm 5.51 \mathrm{~g}) 15$ days after STZ administration.

We examined the expression of glut1 and glut4 glucose transporters. The ratio of glut1 mRNA over glut4
mRNA was significantly higher in brain tissues (cerebellum and frontal cortex) than in the peripheral organs. Glut4 was more expressed in the heart compared to glut1 (Fig. 1).

Both glut1 and glut4 transporters showed an arrhythmic expression profile in the heart and frontal cortex of control and STZ-induced animals (Table 1, 

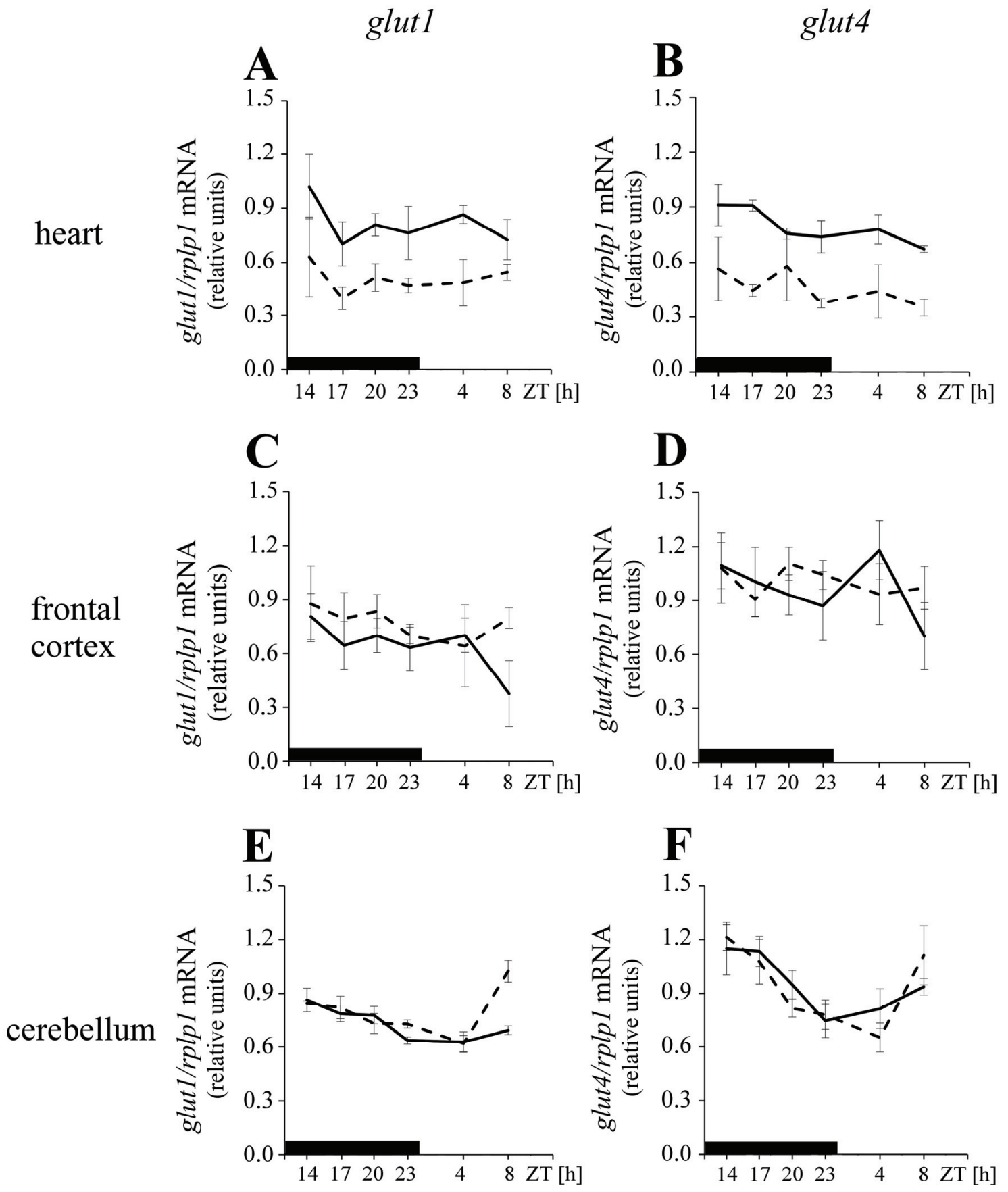

Fig. 2. Daily profile of g/ut1 (A, C, E) and g/ut4 (B, D, F) expression in the heart (A, B), frontal cortex (C, D) and cerebellum (E, F) of control rats (continuous line) and rats with streptozotocin-induced diabetes (dashed line). Glucose transporter expression is normalized to expression of housekeeping gene $r p / p 1$. Animals were synchronized to 12:12 LD cycle. Time is expressed as a Zeitgeber time (ZT) with beginning of the light phase at ZT 0 . Black bar at the bottom of the graph represents the dark period. Values are presented as mean \pm SEM $(n=3-6)$.

Fig. 2). Expression of glut1 and glut4 was rhythmic only in the cerebellum of control and STZ-induced rats. Maximal levels of glut1 and glut4 expression were achieved at the beginning of the dark phase of the 24-h cycle (ZT 14:43, cosinor, $\mathrm{P}<0.01$; ZT 13:52, cosinor, $\mathrm{P}<0.01$, respectively) in the cerebellum of control rats (Table 1, Fig. 2E, 2F). STZ-induced diabetes caused trend to phase advance in cerebellar glutl expression
(Table 1, Fig. 2E).

We observed significant down-regulation of the expression of glut1 and glut4 glucose transporters in the heart of STZ-induced diabetic rats (t-test, $\mathrm{P}<0.0001$ ) (Table 1, Fig. 2A, 2B). STZ treatment did not reduce the mean values of glut1 and glut4 expression in the frontal cortex and cerebellum (t-test, Fig. 2). 


\section{Discussion}

Our study showed different effect of STZinduced diabetes on expression of glut 1 and glut 4 glucose transporters in brain tissues protected by blood-brain barrier compared to periphery. Glucose transporter expression in the heart of STZ-diabetic rats exhibits down-regulation, however this effect was not observed in glut1 and glut4 expression in the frontal cortex and cerebellum. Among examined tissues, only cerebellum showed rhythmic daily profile of glut1 and glut4 expression.

These results partially agree with previous data showing the impact of diabetes on brain tissues. Elevated plasma glucose concentration in diabetic animals is linked with a rise in cerebral extracellular glucose levels (Silver and Erecińska 1994, Jacob et al. 2002, Puchowicz et al. 2004). In our study expression of glut1 and glut4 transporters in the frontal cortex of STZ-treated rats did not differ from that in control rats. Similarly, in previous studies increased glucose levels did not influence the expression of GLUT1 and GLUT4 proteins in the cerebral cortex of STZ-diabetic rats as well as in the brain of hyperglycemic $d b / d b$ mice (Vannucci et al. 1997, Vannucci et al. 1998, Badr et al. 2000, Tang et al. 2000). On the other hand, in spontaneously hyperglycemic nonobese diabetic mice the blood-brain-barrier glucose permeability and GLUT1 transporter velocity was reduced (Cornford et al. 1995). Altered expression of glut1 mRNA and GLUT1 proteins in the brain in diabetic animals was reported in some cases, but the extent of changes varied and no measurements were done specifically in the frontal cortex. It was observed, that the expression of glut 1 mRNA in the brain of $d b / d b$ mice was regionally increased compared to control animals (Vannucci et al. 1997). In brain capillary of rats with STZ-induced diabetes, the level of glut1 mRNA was increased in comparison to control group (Lutz and Pardridge 1993). The expression of both glut1 mRNA and GLUT1 protein was markedly reduced in the whole brains of rats with STZ-induced diabetes compared to expression levels in control group (Hou et al. 2007). The local densities of glucose transporters GLUT1 in the brain of rats with STZ-induced diabetes were lowered in 12 out of 28 investigated brain structures; the GLUT1 densities in remaining examined structures were unchanged (Duelli et al. 2000). However, the measured local cerebral glucose utilization in frontal cortex of STZtreated rats showed a significant increase (Duelli et al. 2000).
Differences in diabetic brain glucose transporter expression can be partially explained by the different duration and model of diabetes. Other factor contributing to diversity of measured glucose transporter expression values is the dissimilar sampling time.

The expression of GLUT4 protein was downregulated in STZ-diabetic rat cerebellum (Vannucci et al. 1998). This is consistent with the trend for lower glut4 mRNA expression values in the cerebellum of STZdiabetic rats observed at certain time points of the 24-h cycle in our study.

Down-regulation of glut1 and glut4 expression outside the blood-brain barrier in the heart of STZ-treated rats in our study correlates with similar effect observed in peripheral tissues in previous studies. Strongly diminished GLUT4 protein expression was found in the heart of rats with STZ- induced diabetes (Camps et al. 1992, Hoenack and Roesen 1996). Down-regulated glut1 and glut4 expression was observed in the heart of rats with acute (7 days) as well as chronic (6 months) STZinduced diabetes (Depre et al. 2000). Reduced glut1 and glut4 expression was detected in the heart, kidney and lung of STZ-diabetic rats; glut1 was down-regulated also in the liver and pancreas of diabetic rats (Jurysta et al. 2013). In other work, STZ-induced diabetes caused increased glut1 and glut4 expression in the kidney and heart, increased glut1 expression in muscle and glut4 expression in the liver. The different character of changes of glut1 and glut4 expression when compared to our results and results of other authors might be explained as a consequence of overnight fasting before the tissue collection (Sokolovska et al. 2011). However, unlike our results, aforementioned authors did not examine the 24-h expression profile of glucose transporter expression.

It is likely that increased glucose and fatty acid levels during diabetes act directly on circadian oscillator functioning in the peripheral tissues (Hirota et al. 2002, Kohsaka et al. 2007). The expression levels of glut1 and glut4 are regulated by insulin in the periphery. This effect is mediated by AMP-activated protein kinase (Barnes et al. 2002, Karnieli and Armoni 2008, McGee et al. 2008). Furthermore, diabetes changes the daily rhythm of locomotor activity and synchronization capacity regulated by central oscillator (Shimazoe et al. 2000, Ramadan et al. 2006). Except for the direct effect of glucose on the molecular oscillator, glucose can affect function of brain oscillators via glucose sensing brain regions (hypothalamus, brain stem, nucleus of the solitary tract (Mizuno and Oomura 1984, Silver and Erecińska 1998, 
Routh 2010, Thorens 2011). We demonstrated that glut1 and glut4 expression in cerebellum, frontal cortex and the heart strongly differ. Their role in regulation of peripheral oscillators requires further research.

To conclude, STZ-induced diabetes exhibits different effects in tissues located inside and outside the blood-brain barrier. In peripheral tissues such as the heart, the expression of glut1 and glut4 was downregulated. In tissues protected by blood-brain barrier, STZ-induced diabetes does not cause decrease in mean levels of glut1 and glut4 transcription. We observed a daily rhythm in glut1 and glut4 expression in the cerebellum and diabetes caused trend to phase advance in glut1 expression in this tissue. Expression of glut1 and glut4 in frontal cortex did not show a daily pattern and their expression was unaffected by diabetes. The reason why cerebellum shows a daily pattern of glut transporters expression, while glut1 and glut4 exerts tonic expression in frontal cortex, needs to be elucidated.

\section{Conflict of Interest}

There is no conflict of interest.

\section{Acknowledgements}

This study was supported by grant VEGA 1/1262/12.

\section{References}

ALBRECHT U: Orchestration of gene expression and physiology by the circadian clock. J Physiol (Paris) 100: 243251, 2006.

ARBLE DM, SANDOVAL DA: CNS control of glucose metabolism: response to environmental challenges. Front Neurosci 7: 20, 2013.

ASCHOFF J: Handbook of Behavioral Neurobiology: IV. Biological Rhythms. Plenum Press, New York, 1981, pp 2560.

BADR GA, TANG J, ISMAIL-BEIGI F, KERN TS: Diabetes downregulates GLUT1 expression in the retina and its microvessels but not in the cerebral cortex or its microvessels. Diabetes 49: 1016-1021, 2000.

BARNARD AR, NOLAN PM: When clocks go bad: neurobehavioural consequences of disrupted circadian timing. PLoS Genet 4: e1000040, 2008.

BARNES K, INGRAM JC, PORRAS OH, BARROS LF, HUDSON ER, FRYER LG, FOUFELLE F, CARLING D, HARDIE DG, BALDWIN SA: Activation of GLUT1 by metabolic and osmotic stress: potential involvement of AMP-activated protein kinase (AMPK). J Cell Sci 115: 2433-2442, 2002.

CAIlotTo C, VAN HEIJNINGEN C, VAn Der VLIET J, VAN DER PLASSE G, HABOLD C, KALSBEEK A, PÉVET P, BUIJS RM: Daily rhythms in metabolic liver enzymes and plasma glucose require a balance in the autonomic output to the liver. Endocrinology 149: 1914-1925, 2008.

CAMPS M, CASTELLÓ A, MUÑOZ P, MONFAR M, TESTAR X, PALACÍN M, ZORZANO A: Effect of diabetes and fasting on GLUT-4 (muscle/fat) glucose-transporter expression in insulin-sensitive tissues. Heterogeneous response in heart, red and white muscle. Biochem J 282: 765-772, 1992.

CHALLET E: Interactions between light, mealtime and calorie restriction to control daily timing in mammals. $J$ Comp Physiol B 180: 631-644, 2010.

CHALLET E, LOSEE-OLSON S, TUREK FW: Reduced glucose availability attenuates circadian responses to light in mice. Am J Physiol 276: 1063-1070, 1999.

CHOMCZYNSKI P, SACCHI N: Single-step method of RNA isolation by acid guanidinium thiocyanate phenolchloroform extraction. Anal Biochem 162: 156-159, 1987.

CORNFORD EM, HYMAN S, CORNFORD ME, CLARE-SALZLER M: Down-regulation of blood-brain glucose transport in the hyperglycemic nonobese diabetic mouse. Neurochem Res 20: 869-873, 1995.

DEPRE C, YOUNG ME, YING J, AHUJA HS, HAN Q, GARZA N, DAVIES PJ, TAEGTMEYER H: Streptozotocininduced changes in cardiac gene expression in absence of severe contractile dysfunction. $J$ Mol Cell Cardiol 32: 985-996, 2000.

DUELLI R, KUSCHINSKY W: Brain glucose transporters: relationship to local energy demand. News Physiol Sci 16: 71-76, 2001. 
DUELLI R, MAURER MH, STAUDT R, HEILAND S, DUEMBGEN L, KUSCHINSKY W: Increased cerebral glucose utilization and decreased glucose transporter Glut1 during chronic hyperglycemia in rat brain. Brain Res 858: 338-347, 2000.

EBELING P, KOISTINEN HA, KOIVISTO VA: Insulin-independent glucose transport regulates insulin sensitivity. FEBS Lett 436: 301-303, 1998.

FROY O: Metabolism and circadian rhythms - implications for obesity. Endocr Rev 31: 1-24, 2010.

HERICHOVÁ I, ZEMAN M, STEBELOVÁ K, RAVINGEROVÁ T: Effect of streptozotocin-induced diabetes on daily expression of per2 and dbp in the heart and liver and melatonin rhythm in the pineal gland of Wistar rats. Mol Cell Biochem 270: 223-229, 2005.

HIROTA T, OKANO T, KOKAME K, SHIROTANI-IKEJIMA H, MIYATA T, FUKADA Y: Glucose down-regulates Per1 and Per2 mRNA levels and induces circadian gene expression in cultured rat-1 fibroblasts. $J$ Biol Chem 277: 44244-44251, 2002.

HOENACK C, ROESEN P: Inhibition of angiotensin type 1 receptor prevents decline of glucose transporter (GLUT4) in diabetic rat heart. Diabetes 45 (Suppl 1): S82-S87, 1996.

HOU WK, XIAN YX, ZHANG L, LAI H, HOU XG, XU YX, YU T, XU FY, SONG J, FU CL, ZHANG WW, CHEN L: Influence of blood glucose on the expression of glucose trans-porter proteins 1 and 3 in the brain of diabetic rats. Chin Med J (Engl) 120: 1704-1709, 2007.

ICHIKAWA M, KANAI S, ICHIMARU Y, FUNAKOSHI A, MIYASAKA K: The diurnal rhythm of energy expenditure differs between obese and glucose-intolerant rats and streptozotocin-induced diabetic rats. $J$ Nutr 130: 2562-2567, 2000.

IWANAGA H, YANO M, MIKI H, OKADA K, AZAMA T, TAKIGUCHI S, FUJIWARA Y, YASUDA T, NAKAYAMA M, KOBAYASHI M, OISHI K, ISHIDA N, NAGAI K, MONDEN M: Per2 gene expressions in the suprachiasmatic nucleus and liver differentially respond to nutrition factors in rats. JPEN $J$ Parenter Enteral Nutr 29: 157-161, 2005.

JACOB RJ, FAN X, EVANS ML, DZIURA J, SHERWIN RS: Brain glucose levels are elevated in chronically hyperglycemic diabetic rats: no evidence for protective adaptation by the blood brain barrier. Metabolism 51: 1522-1524, 2002.

JURYSTA C, NICAISE C, GIROIX MH, CETIK S, MALAISSE WJ, SENER A: Comparison of GLUT1, GLUT2, GLUT4 and SGLT1 mRNA expression in the salivary glands and six other organs of control, streptozotocininduced and Goto-Kakizaki diabetic rats. Cell Physiol Biochem 31: 37-43, 2013.

KALSBEEK A, LA FLEUR S, VAN HEIJNINGEN C, BUIJS RM: Suprachiasmatic GABAergic inputs to the paraventricular nucleus control plasma glucose concentrations in the rat via sympathetic innervations of the liver. J Neurosci 24: 7604-7613, 2004.

KARNIELI E, ARMONI M: Transcriptional regulation of the insulin-responsive glucose transporter GLUT4 gene: from physiology to pathology. Am J Physiol 295: E38-E45, 2008.

KLEMFUSS H, CLOPTON PL: Seeking tau: a comparison of six methods. $J$ Interdiscip Cycle Res 24: 1-16, 1993.

KOHSAKA A, LAPOSKY AD, RAMSEY KM, ESTRADA C, JOSHU C, KOBAYASHI Y, TUREK FW, BASS J: High-fat diet disrupts behavioral and molecular circadian rhythms in mice. Cell Metab 6: 414-421, 2007.

LA FLEUR SE: Daily rhythms in glucose metabolism: suprachiasmatic nucleus output to peripheral tissue. J Neuroendocrinol 15: 315-322, 2003.

LA FLEUR SE, KALSBEEK A, WORTEL J, BUIJS RM: A suprachiasmatic nucleus generated rhythm in basal glucose concentrations. J Neuroendocrinol 11: 643-652, 1999.

LA FLEUR SE, KALSBEEK A, WORTEL J, FEKKES ML, BUIJS RM: A daily rhythm in glucose tolerance: a role for the suprachiasmatic nucleus. Diabetes 50: 1237-1243, 2001.

LAPOSKY AD, BASS J, KOHSAKA A, TUREK FW: Sleep and circadian rhythms: key components in the regulation of energy metabolism. FEBS Lett 582: 142-151, 2008.

LEE A, ADER M, BRAY GA, BERGMAN RN: Diurnal variation in glucosetolerance. Cyclic suppression of insulin action and insulin secretion in normal-weight, but not obese, subjects. Diabetes 41: 742-749, 1992.

LUTZ AJ, PARDRIDGE WM: Insulin therapy normalizes GLUT1 glucose transporter mRNA but not immunoreactive transporter protein in streptozocin-diabetic rats. Metabolism 42: 939-944, 1993. 
MCGEE SL, VAN DENDEREN BJ, HOWLETT KF, MOLLICA J, SCHERTZER JD, KEMP BE, HARGREAVES M: AMP-activated protein kinase regulates GLUT4 transcription by phosphorylating histone deacetylase 5. Diabetes 57: 860-867, 2008.

MIZUNO Y, OOMURA Y: Glucose responding neurons in the nucleus tractus solitarius of the rat, in vitro study. Brain Res 307: 109-116, 1984.

NELSON W, TONG YL, LEE JK, HALBERG F: Methods for cosinor-rhythmometry. Chronobiologia 6: 305-323, 1979.

OISHI K, KASAMATSU M, ISHIDA N: Gene- and tissue-specific alterations of clock gene expression in streptozotocin-induced diabetic mice under restricted feeding. Biochem Biophys Res Commun 317: 330-334, 2004.

OISHI K, UCHIDA D, OHKURA N, DOI R, ISHIDA N, KADOTA K, HORIE S: Ketogenic diet disrupts the circadian clock and increases hypofibrinolytic risk by inducing expression of plasminogen activator inhibitor-1. Arterioscler Thromb Vasc Biol 29: 1571-1577, 2009.

PUCHOWICZ MA, XU K, MAGNESS D, MILLER C, LUST WD, KERN TS, LAMANNA JC: Comparison of glucose influx and blood flow in retina and brain of diabetic rats. J Cereb Blood Flow Metab 24: 449-457, 2004.

RAMADAN W, DEWASMES G, PETITJEAN M, LOOS N, DELANAUD S, GELOEN A, LIBERT JP: Spontaneous motor activity in fat-fed, streptozotocin-treated rats: a nonobese model of type 2 diabetes. Physiol Behav 87: 765-772, 2006.

RERUP CC: Drugs producing diabetes through damage of the insulin secreting cells. Pharmacol Rev 22: 485-518, 1970.

ROUTH VH: Glucose sensing neurons in the ventromedial hypothalamus. Sensors 10: 9002-9025, 2010.

SHEARMAN LP, SRIRAM S, WEAVER DR, MAYWOOD ES, CHAVES I, ZHENG B, KUME K, LEE CC, VAN DER HORST GT, HASTINGS MH, REPPERT SM: Interacting molecular loops in the mammalian circadian clock. Science 288: 1013-1019, 2000.

SHIMAZOE T, ISHIDA J, MAETANI M, YAKABE T, YAMAGUCHI M, MIYASAKA K, KONO A, WATANABE S, FUNAKOSHI A: Entrainment function in the suprachiasmatic nucleus of streptozotocin-induced diabetic rats. Jpn J Pharmacol 83: 355-358, 2000.

SILVER IA, ERECIŃSKA M: Extracellular glucose concentration in mammalian brain: continuous monitoring of changes during increased neuronal activity and upon limitation in oxygen supply in normo-, hypo-, and hyperglycemic animals. J Neurosci 14: 5068-5076, 1994.

SILVER IA, ERECIŃSKA M: Glucose-induced intracellular ion changes in sugar-sensitive hypothalamic neurons. J Neurophysiol 79: 1733-1745, 1998.

SOKOLOVSKA J, ISAJEVS S, SUGOKA O, SHARIPOVA J, LAUBERTE L, SVIRINA D, ROSTOKA E, SJAKSTE T, KALVINSH I, SJAKSTE N: Correction of glycaemia and GLUT1 level by mildronate in rat streptozotocin diabetes mellitus model. Cell Biochem Funct 29: 55-63, 2011.

ŠOLTÉSOVÁ D, HERICHOVÁ I: On the mechanisms of diabetogenic effects of alloxan and streptozotocin. Diabetologie, metabolismus, endokrinologie, výživa 14: 130-138, 2011.

TAKAHASHI JS, HONG HK, KO CH, MCDEARMON EL: The genetics of mammalian circadian order and disorder: implications for physiology and disease. Nat Rev Genet 9: 764-775, 2008.

TANG J, ZHU XW, LUST WD, KERN TS: Retina accumulates more glucose than does the embryologically similar cerebral cortex in diabetic rats. Diabetologia 43: 1417-1423, 2000.

THORENS B: Brain glucose sensing and neural regulation of insulin and glucagon secretion. Diabetes Obes Metab $\mathbf{1 3}$ (Suppl 1): 82-88, 2011.

VANNUCCI SJ, GIBBS EM, SIMPSON IA: Glucose utilization and glucose transporter proteins GLUT-1 and GLUT-3 in brains of diabetic (db/db) mice. Am J Physiol 272: E267-E274, 1997.

VANNUCCI SJ, KOEHLER-STEC EM, LI K, REYNOLDS TH, CLARK R, SIMPSON IA: GLUT4 glucose transporter expression in rodent brain: effect of diabetes. Brain Res 797: 1-11, 1998. 
WU T, ZHUGE F, SUN L, NI Y, FU O, GAO G, CHEN J, KATO H, FU Z: Enhanced effect of daytime restricted feeding on the circadian rhythm of streptozotocin-induced type 2 diabetic rats. Am J Physiol 302: E1027E1035, 2012.

YOUNG ME, WILSON CR, RAZEGHI P, GUTHRIE PH, TAEGTMEYER H: Alterations of the circadian clock in the heart by streptozotocin-induced diabetes. J Mol Cell Cardiol 34: 223-231, 2002. 